\title{
Short-term radioactive disequilibrium in thermal mineral waters in Karlovy Vary (Carlsbad) spa, Czech Republic
}

\author{
V. Goliáš ${ }^{1}$, T. Vylita ${ }^{2}$, Z. Tŕískala ${ }^{1}$, R. Procházka ${ }^{1}$ and D. Pittauerová ${ }^{1,3}$ \\ ${ }^{1}$ Charles University in Prague, Faculty of Science, Department of Geochemistry, Mineralogy \\ and Mineral Resources, Albertov 6, 12843 Prague 2, Czech Republic \\ ${ }^{2}$ Mineral Water Bureau of Karlovy Vary, Lázeňská 2, 36001 Karlovy Vary, Czech Republic \\ ${ }^{3}$ University of Bremen, Department of Physics, Otto-Hahn-Alle 1, 28334 Bremen, Germany
}

\section{INTRODUCTION}

The history of foundation of the famous Czech spa city Karlovy Vary goes back to 1350. The curative effects of Karlovy Vary thermal waters were widely used for balneological cures since the $16^{\text {th }}$ century. Increased radioactivity of Karlovy Vary waters has been known for a long time. Mache and Meyer realized the first measurement in 1905. Present contribution is focused on state of radioactive equilibrium of Karlovy Vary hot springs.

Mineral waters of Karlovy Vary area are sulphate - bicarbonate waters (TDS about $6 \mathrm{~g} / \mathrm{l}$ ) with high concentrations of dissolved $\mathrm{CO}_{2}$. During the process of water up-welling (evasion) $\mathrm{CO}_{2}$ liberating can in some cases (e.g. "Hot spring") represent up to $75 \%$ of the spring's total volume production. The temperature (range from $10^{\circ} \mathrm{C}$ up to $73^{\circ} \mathrm{C}$ ) depends on the particular springs' distance from the main fault zone. The thermal springs are connected with the long-term aragonite sinter banks formation (Vylita et al., 2007).

\section{MATERIALS AND METHODS}

\subsection{The measuring device}

\subsubsection{Gamma spectroscopy}

A temporary "in-situ" laboratory was constructed in the center of the spa area. Scintillation based gamma-spectroscopy with $75 \times 75 \mathrm{~mm} \mathrm{NaI}(\mathrm{Tl})$ crystal (energy resolution $7.1 \%$ ) with Canberra DSA2000 controlled by GENIE 2000 software was used for determination of total gamma activity and ${ }^{214} \mathrm{~Pb}$ and ${ }^{214} \mathrm{Bi}$ volume activities.

\subsubsection{Shielding}

Shielding made of $7 \mathrm{~cm} \mathrm{~Pb}$ and $1 \mathrm{~mm} \mathrm{Cu}$ was installed around the detector to the natural background suppression. Cooling and venting of apparatus was installed.

\subsubsection{Special beakers}

Classical thin-wall polypropylene Marinelli beakers could not be used for sampling because of the pressure changes due to the either $\mathrm{CO}_{2}$ gas dissolving or evasion from the water. In this project containers made of HDPE polyethylene with a wide high-pressure screw and silicone rubber sealing were used. Full beaker contained 1.5 liter of the water and 0.3 liter of air. 


\subsection{4 "Protective" cooler with thermocouple}

The use of $\mathrm{NaI}(\mathrm{Tl})$ crystal detector requires the cooler to protect the crystal from the thermal shift and mainly from the damage (rupture). The cooler was inserted in-between the sample beaker and the detector. For this purpose a thick-walled $3 \mathrm{~mm}$ aluminum liner (between two layers of foam insulation) cooled by the through running cold water was used. To monitor the function of the cooler a probe of the thermocouple was placed at the face of the detector. The detection unit was moreover active cooled by the additional air boosting. The maximal registered absolute thermal shift was $1.5^{\circ} \mathrm{C}$ in case of the hottest sample.

\subsection{Sampling procedure \& data acquiring}

Sampling started by filling the special Marinelli beaker directly at the outflow vase of the spring. The transport distance between the spring vase and the laboratory caused some delay between the sample collecting and the start of the measuring, although usually not more than 3 minutes. Acquiring the activity of samples was realized in time series of 5 minutes spectral counting for 5 hours. Totally 60 spectra from the each sample were collected. For activities calculation ${ }^{226} \mathrm{Ra}$ standard solution aliquot (EB6 type, Czech Metrology Institute) was measured in the same geometry. For comparison ${ }^{222} \mathrm{Rn}$ activities in waters were also established by ionization chamber.

\section{RESULTS AND CONCLUSIONS}

\subsection{Observed activities \& trends}

From the spectral data volume activities of ${ }^{214} \mathrm{~Pb},{ }^{214} \mathrm{Bi}$ (as only detected radionuclides) and total gamma activity were calculated. The activities progression is the most dramatic just after the sampling. Two types of the activity evolution were observed in general. Some water samples show increasing trend (progeny $<{ }^{222} \mathrm{Rn}$ ) (Fig. 1) and other show rapid decreasing trend (progeny $>{ }^{222} \mathrm{Rn}$ ) of their gamma activities (Fig. 2).

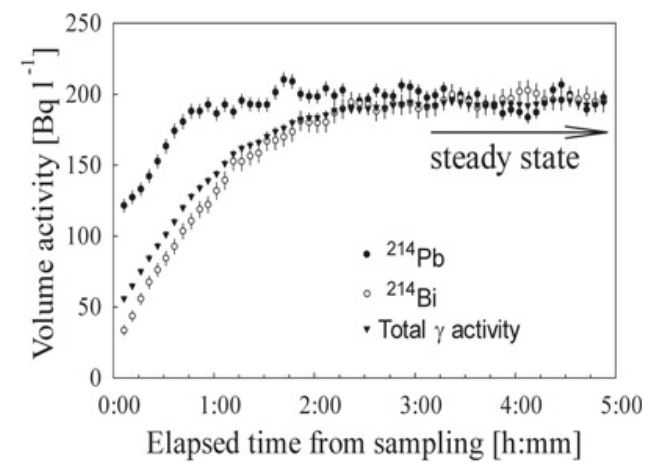

Figure 1. Activity progression of the Hadí spring. Example of increasing activity trend.

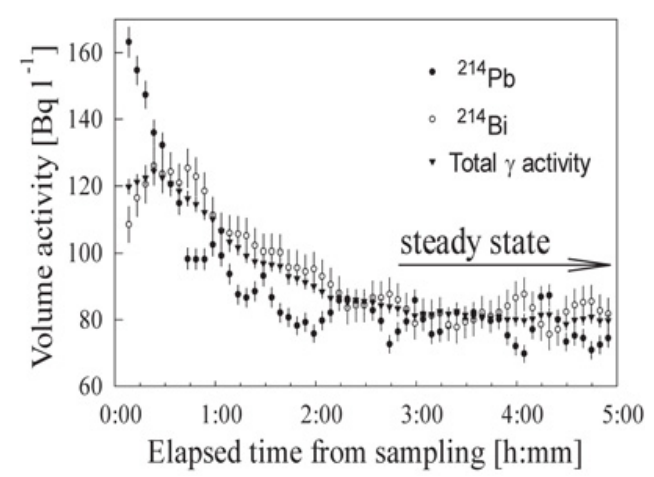

Figure 2. Activity progression of the Sadový starý spring. Example.

Three hours after sampling steady state (Fig. 3) was reached. It represents the equilibrium of radon and its progeny, when their volume activities are equal. The final steady state gamma activities (they represent radon volume activities) of 18 springs vary in the range from 6.6 up to $567 \mathrm{~Bq}^{-1}{ }^{222} \mathrm{Rn}$ (Table 1). 


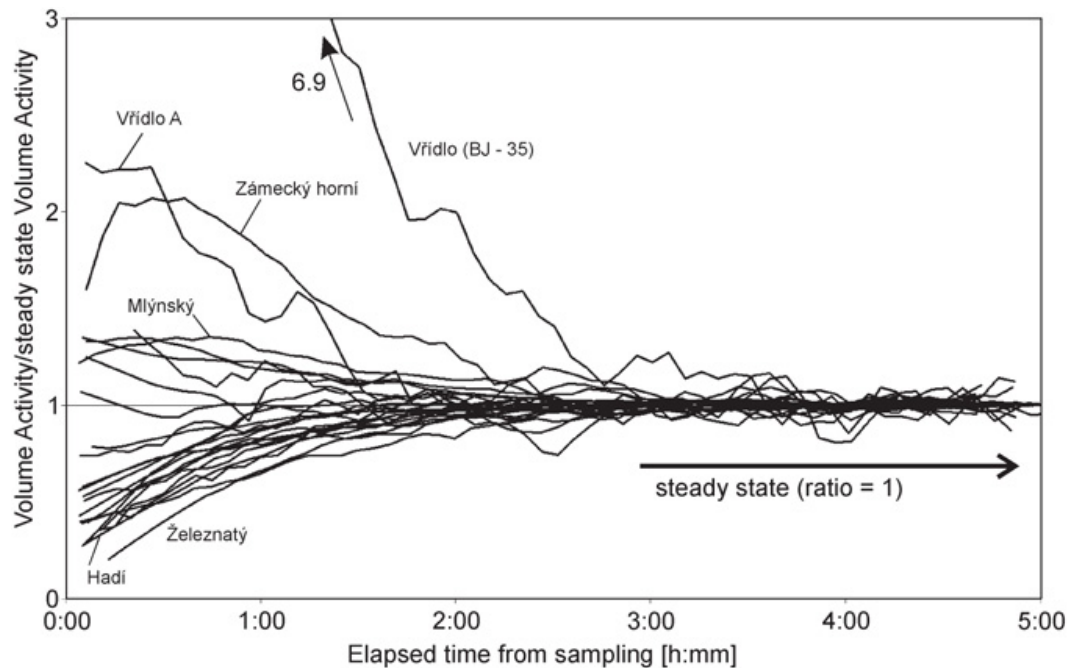

Figure 3. Normalized total gamma activities of all water samples. Dramatic activity progression from sampling to steady state (equilibrium of radon-222 and its progeny) is obvious.

Table 1. The summary table of initial and steady activities of the Karlovy Vary spa thermal springs. The observed activity trend and temperature are completed.

\begin{tabular}{|c|c|c|c|c|c|c|c|}
\hline \multirow{3}{*}{ No. } & \multirow{3}{*}{$\begin{array}{c}\mathbf{t} \\
{\left[{ }^{\circ} \mathrm{C}\right]}\end{array}$} & \multirow{3}{*}{ spring } & \multicolumn{4}{|c|}{ Volume $\gamma$ activity } & \multirow{3}{*}{ trend } \\
\hline & & & \multicolumn{2}{|c|}{ [Bq/l eRn] } & \multicolumn{2}{|c|}{ [Bq// Rn] } & \\
\hline & & & initial & $1 \sigma$ & $\begin{array}{c}\text { steady } \\
\text { state }\end{array}$ & $1 \sigma$ & \\
\hline 1 & 72.2 & Vř́idlo (BJ - 35) & 51 & 2.7 & 7.40 & 0.17 & decrease \\
\hline $1 \mathrm{a}$ & 70.0 & Vřidlo A & 16 & 1.9 & 6.89 & 0.27 & decrease \\
\hline 1c & 30.0 & Vřídlo C & 9 & 1.7 & 7.10 & 0.23 & decrease \\
\hline 1d & 37.0 & Vřídlo balneotherapy & 17 & 2.0 & 12.77 & 0.28 & decrease \\
\hline 2 & 64.3 & Karel IV. & 6 & 1.6 & 12.17 & 0.23 & growth \\
\hline 4 & 56.7 & Zámecký Horní & 26 & 2.2 & 16.53 & 0.70 & decrease \\
\hline 3 & 59.0 & Zámecký Dolní & 12 & 1.8 & 20.96 & 0.27 & growth \\
\hline 5 & 64.6 & Tržni & 2 & 1.4 & 6.59 & 0.30 & growth \\
\hline 6 & 56.6 & Mlýnský & 39 & 2.5 & 29.88 & 0.43 & decrease \\
\hline 7 & 60.9 & Rusalka & 8 & 1.7 & 18.88 & 0.48 & growth \\
\hline $8 \mathbf{a}$ & 66.8 & Kniže Václav I. & 7 & 1.6 & 18.26 & 0.23 & growth \\
\hline $8 b$ & 63.1 & Kniže Václav II. & 7 & 1.6 & 12.92 & 0.30 & growth \\
\hline 9 & 62.7 & Libuše & 14 & 1.9 & 18.75 & 0.25 & growth \\
\hline 10 & 46.9 & Skalní - směs & 20 & 2.0 & 54.24 & 0.22 & growth \\
\hline 11 & 62.4 & Svobody & 4 & 1.5 & 12.35 & 0.24 & growth \\
\hline 12 & 41.6 & Sadový & 20 & 2.1 & 51.64 & 0.28 & growth \\
\hline 14 & 13.4 & Štěpánka & 57 & 2.6 & 72.82 & 0.25 & growth \\
\hline 15 & 28.7 & Hadí & 47 & 2.6 & 193.48 & 0.63 & growth \\
\hline $27 a$ & 37.8 & Palatin & 49 & 2.7 & 305.89 & 0.81 & growth \\
\hline $32 \mathrm{c}$ & 51.2 & Mlýnský starý & 62 & 3.0 & 111.89 & 0.89 & growth \\
\hline $43 a$ & 53.9 & Tereziiny & 22 & 2.1 & 71.36 & 0.36 & growth \\
\hline 64 & 45.2 & Sadový starý & 120 & 3.8 & 80.75 & 0.55 & decrease \\
\hline 84 & 14.3 & Železnatý & 116 & 3.8 & 567.15 & 4.90 & growth \\
\hline
\end{tabular}




\subsection{Mathematical modeling}

The time of equilibrium evolution was mathematically modeled and the experimentally obtained data were fitted into the model. Increasing trend, where the progenies are generated from dissolved radon, corresponds to the theoretical model. Anomalous decreasing trend of activities gives evidence of the presence of a huge portion of the "foreign" progeny (mainly ${ }^{218} \mathrm{Po}$ ) in fresh up-welling water. This causes the situation when the initial activities are higher than matches to the radon volume activity.

Anomalous decreasing trend of gamma activities was determined especially in cases of the hottest, highly gaseous springs. These "foreign" progeny come from dissolved radon decay before evasion and also from their elution from spring gas during their common progress to the surface.

\subsection{The radioactivity trends \& Karlovy Vary spa drinking cure}

The therapeutic effect of radioactive waters with dissolved radon based on low radiation doses, so called radiation hormesis, was repeatedly proven by researches (Deetjen et al., 2005). From the balneological point of view it is evident, what the waters with increasing trends will be most effective after reaching radioactive equilibrium. On the other hand, waters with decreasing trends e.g. the most favourite Mlýnský (Mill) spring and Vřídlo (Hot spring) will be most effective just in time of its outlet, realized as known "Karlovy Vary drinking cure" from the beginning of times. In that case the relatively high activities of radon progeny can be one from the important factors for the digestive tract illnesses therapy.

\section{Acknowledgments}

For the financial support we want to thank to the Grant Agency of the Czech Republic, project No 205/07/0522.

\section{References}

[1] Mache, H. and S. Meyer S, 1905. Über die Radioaktivität der Quellen der böhmischen Bädergruppe: Karlsbad, Marienbad, Teplitz-Schönau-Dux, Franzensbad sowie von St. Joachimsthal. Aus den Sitzungsbereichten der kaiserl. Akademie der Wissenschaften in Wien. Mathem.-naturw. Klasse. 114. Abt. II.a. Wien. 1-30.

[2] Vylita, T., K. Zak, V. Cilek, H. Hercman and L. Miksikova, 2007. Evolution of hot-spring travertine accumulation in Karlovy Vary/Carsbad (Czech Republic) and its significance for the evolution of Tepla valley and Ohre/Eger rift. Zeitschrift fut Geomorfologie, 51 (4): 427-442.

[3] Deetjen P., A. Falkenbach, D. Harder, H. Jöckel, A. Kaul and H. V. Philipsborn, 2005. Radon als Heilmittel. Therapeutische Wirksamkeit, biologischer Wirkungsmechanismus und vergleichende Risikobewertung. - Verlag Dr. Kovač. Hamburg. 111p. 